\title{
ソフトプロセスによる黒鉛層間化合物の合成
}

\section{Synthesis of graphite intercalation compounds by a soft process}

\section{安部武志*}

Takeshi Abe*

\section{1. はじめに}

黒鉛は炭素六角網目平面が弱いファンデルワールスカにより 積層しているため, その層間に多くの原子, 分子が挿入され黒鉛 層間化合物 (Graphite Intercalation Compounds, 以下 GIC と略 記）を形成することが知られている。挿入される物質をインター カレート (intercalate) と呼び, 典型的なインターカレートには, アルカリ金属, ハロゲン, 酸, 金属塩化物などが知られている。 GIC は高い電子伝導性を示すことから, その電子物性を中心に構 造, 格子動力学, 磁性などが調べられている。また, 小型携帯機器 用電源として不可欠なリチウムイオン電池の負極ではリチウム イオンの挿入脱離, すなわち, リチウム-GICの生成 ·分解反応を利 用し, 充放電反応が生じている。このようにGICは基礎研究から 実用面での研究開発の対象になっており,これまでに数多くの研 究がなされてきている。これらについては総説や最近出版され たGICに関する書籍を参照されたい1)-4)。

GICの合成法には種々知られており,インターカレートの蒸気と 黒鉛を接触させることにより GICを作製する気相法, 液相中に存 在するインターカレートを黒鉛と反応させる液相法, もしくは, 一 部の GICでは固相／固相の接触により作製可能なものも存在す る。ここでは低温でGICを作製する, いわゆる, ソフトプロセス による GIC 合成法について紹介する。

\section{2. アルカリ金属-GICの合成}

アルカリ金属-GICを液相から合成する手法として2種類ある。 1つは化学的な手法であり, 他方は電気化学的手法である。まず, 前者について述べる。いわゆる溶液法と呼ばれる化学的手法に よりアルカリ金属-GICを合成する場合, 実験はグローブボックス で行うことが好ましいが, 簡易グローブバック中もしくは大気中 でも可能である。実際, 筆者が学生のときは大気中で行っていた。

アルカリ金属-GICを合成する場合, メトキシプロパン (MP) も しくはメトキシブタン $(\mathrm{MB})$ などの有機溶媒 $2 \mathrm{ml}$ を気密性の高 いバイアル瓶 (シリコーンパッキン付のスクリュー管, マイティ

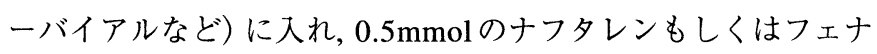
ントレンを有機溶媒に溶解させる。これにアルカリ金属を加え ると,アルカリ金属一有機溶媒一ナフタレンの錯体が生成し, 濃 青色の溶液となる。大気中で行う場合, 有機溶媒中に保存してあ
るアルカリ金属の少量の固まりを流動パラフィンの中にすばやく 入れ,アルカリ金属の表面に流動パラフィンをコートすることに よってアルカリ金属の酸化を抑制する。はさみでアルカリ金属 の固まりをさらに細かく切断し，すばやくナフタレンが溶解した 有機溶媒の中に入れる。バイアル瓶の蓋をよく閉め, さらにシール テープ（バルカー®など）を巻くことによって溶液の酸化を防ぐ ことができる。これにより 1 カ月程度, 溶液は酸化されず濃青色 を保つことが可能である。アルカリ金属の切断面は酸化膜に覆 われていないため, そこからアルカリ金属がイオンとして溶媒中 に溶け出す。溶液の色が十分に濃青色になったことを確認 (大気 中で行う場合は, 濃青色になるまで数時間程度要する場合もある) した後, 黒鉛を速やかに入れ，上述と同様の操作を行うことによ り気密性を保つ。筆者が行っていたときにはフレーク状の天然 黒鉛を用いていたため, 黒鉛をステンレスメッシュに包み, これ を溶液中に浸漬させていた。高配向性熱分解黒鉛 (HOPG) やグ ラフォイルなどではステンレスメッシュに包む必要はないが, 黒 鉛表面にアルカリ金属が付着する場合があるため,この場合もス テンレスメッシュ中に保持するほうが望ましい。図1にバイアル 瓶を用いた反応管の概略図を示す。

黒鉛を溶液中に浸漬させた後はバイアル瓶をそのまま静置さ せてもよいが, 反応をできるだけ促進させるために常にバイアル 瓶を攪拌するほうがよい。血液を採取したときに凝固を防ぐた めの攪拌器 (ミックスローターなど) を購入していれば, その上 にバイアル瓶を設置し, 1〜7日程度攪拌することによって目的 の GICを得ることができる。大きめのバイアル瓶を用い, スターラ 一を用いてもよい。

メトキシブタン, メトキシプロパンを用いた場合, ナトリウム を除く, すべてのアルカリ金属で二元系のアルカリ金属-GICを合

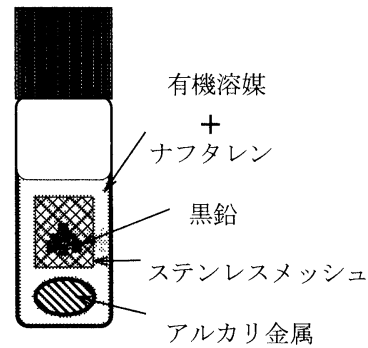

図1 反応管の概略図 


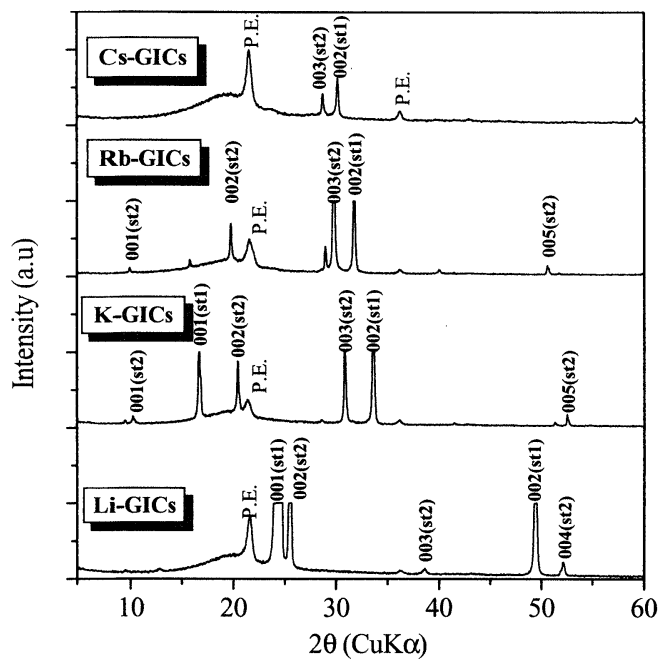

図2 アルカリ金属一ナフタレンーメトキシブタン錯体中で黒 鉛を浸漬させて合成した GICのX線回折パターン：st1, st2, P.E.はそれぞれステージ 1,2 およびポリエチレンのピ 一クを表し, ピーク上の数字は $00 l$ 回折線を示す

表1アルカリ金属一有機溶媒の組み合わせと生成する GIC

\begin{tabular}{l|c|c|c|c|c}
\hline 溶媒 & $\mathrm{Li}$ & $\mathrm{Na}$ & $\mathrm{K}$ & $\mathrm{Rb}$ & $\mathrm{Cs}$ \\
\hline THF & $\mathrm{T}$ & $\mathrm{T}$ & $\mathrm{T}$ & $\mathrm{T}$ & $\mathrm{T}$ \\
2-MeTHF & $\mathrm{B}$ & $\mathrm{B}$ & $\mathrm{B}$ & $\mathrm{B}, \mathrm{T}$ & $\mathrm{B}, \mathrm{T}$ \\
\hline MP & $\mathrm{B}$ & & $\mathrm{B}$ & $\mathrm{B}$ & $\mathrm{B}$ \\
MB & $\mathrm{B}$ & & $\mathrm{B}$ & $\mathrm{B}$ & $\mathrm{B}$ \\
DME & $\mathrm{T}$ & $\mathrm{T}$ & $\mathrm{T}$ & $\mathrm{T}$ & $\mathrm{B}$ \\
DEE & $\mathrm{T}$ & $\mathrm{T}$ & $\mathrm{B}, \mathrm{T}$ & $\mathrm{B}$ & $\mathrm{B}$ \\
DBE & $\mathrm{B}$ & & $\mathrm{B}$ & $\mathrm{B}$ & $\mathrm{B}$ \\
\hline
\end{tabular}

THF：テトラヒドロフラン, 2-MeTHF：2-メチルテトラヒドロフラン, MP：メトキシプロパン, MB：メトキシブタン, DME：1,2-ジメトキ シエタン,DEE：1,2-ジエトキシエタン, DBE：1,2-ジブトキシエタン

成することができる5)。次に得られた試料についてX 線回折測定 を行う場合の操作を記す。

X線回折測定について大気中でサンプルホルダーに設置する必 要がある場合, 速やかに操作する必要がある。溶液中に浸漬した 黒鉛を含んだステンレスメッシュを取り出し, 流動パラフィン中 に浸漬させ, 上述と同様に酸化分解をできるだけ抑制させる。ス テンレスメッシュからサンプルを取り出し, ポリエチレンフィル ム $(20 \mu \mathrm{m}$ のものが望ましい) 2枚の中にサンプルを設置し, ヒー トシーラーによりサンプルをポリエチレンフィルム中に封入す る。X線回折測定用のガラスホルダーにポリエチレンフィルムを 貼り付け, 測定を行う。この操作でサンプルの酸化分解を抑制す ることができる。グローブボックス中でX線回折用気密ホルダ 一にサンプルを設置できれば望ましいが, 本手法でも測定は十分に 可能である。

反応時間を7日間としたときのX線回折パターンを図2に示す。 ポリエチレンフィルム内に封入する際には鮮やかな金色のサ ンプルを確認でき,いわゆるステージ1アルカリ金属-GICの生成 が認められる6)。X線回折パターンからはステージ1 GICにステ ージ2のものが混在していることがわかる。気密ホルダーにより

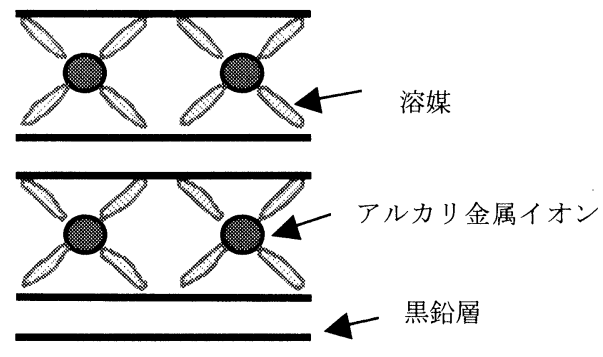

図3 代表的な三元系GICであるステージ2 Li-THF-GICの模式図

測定した場合は, ステージ1 GICのみが得られていることから, 測 定中に若干分解したと考えられる。

メトキシブタン,メトキシプロパンではナトリウム-GICを得る ことができなかったが, 2-メチルテトラヒドロフラン（2-MeTHF） を用いることによりナトリウム-GICを得ることができる。

アルカリ金属と有機溶媒の組み合わせによっては, 溶媒和アル カリ金属イオンが黒鉛に挿入した三元系アルカリ金属一有機溶 媒－GICが合成される。表1には本手法で用いることができる 代表的な有機溶媒と得られる GICの種類を示した。表中のB は 二元系, Tは有機溶媒も挿入した三元系を示す5)。ここで二元系 とは侵入種がアルカリ金属のみであり,これと黒鉛からなる GIC を示し，三元系ではさらに有機溶媒が挿入したGICを示す。例え ば,リチウムイオンにテトラヒドロフランが溶媒和した三元系LiTHF-GICでは図3のようにリチウムイオンに対し,テトラヒドロ フランが正四面体位置にくるように配位した構造になっている ことが報告されている7)。表1からわかるようにアルカリ金属と 有機溶媒の組み合わせによっては二元系と三元系の混在したGIC が得られる。この手法で用いた溶液は還元性の強いものである ため, 実験が終了した後に速やかに処理することが望ましい。具体 的には溶液を大きめのビーカーに移し, 可燃性のものが周囲にない ことを確認してから, メタノールを適量加えることによって溶液 は無色透明となる。残存するアルカリ金属もアルコキシドとな る。この溶液は有機廃液として処理すればよい。

次に電気化学的手法によるアルカリ金属-GICの合成について 示す。電気化学的手法の場合, 筆者は大気中で実験を行った経験が ないが化学的手法で行った場合と同様に酸化分解を抑制する工夫 をすることにより, 大気中でも実験は可能であろう。以下はすべ てグローブボックス中,アルゴン雲囲気下で行った内容である。

電気化学的手法であるためセルが必要となる。GICの合成の みに着目するのであれば二電極式セルで十分であり，また，ステ ージ1 GICのみを合成する場合, 電位や電流を制御する電気化学 装置は必要ない。まずは, 二電極式セルを用いたステージ1 LiGICの簡易合成法を紹介する。この場合, セルも非常に簡単に作 製することができる。バイアル瓶を用意し，この中に電解液を適量 入れる。電解液にはエチレンカーボネート $(\mathrm{EC})$, ジエチルカー ボネート（DEC）を体積比 1 対 1 で混合した溶媒に $1 \mathrm{~mol} \mathrm{dm}^{-3}$ $\mathrm{LiClO}_{4}$ を溶解させたものを購入する（実験室レベルの量であれ ばキシダ化学より購入可能である)。この電解液は溶媒と電解質 塩をそれぞれ購入して作製することができるが, 過塩素酸塩を有機 
溶媒に溶解させる操作を伴うため, あまりお蔍めはできない。研究 室で作製する場合であれば, 過塩素酸塩の代わりに $\mathrm{LiCF}_{3} \mathrm{SO}_{3}$ (も しくは高価であるがイミト塩)を用いるほうがよい。シリコーン を適切な大きさに加工し, バイアル瓶の蓋とする。このシリコーン 栓にニノケル線を 2 本貫通させ,一方のニノケル線の先端にはり チウム金属を他方の先端には里鉛を設置する。リチウム金属は 柔らかいのでニノケル線の先端とリチウム金属をピンセノトでは さみ, 少し圧をかけて押さえることによって簡単に設置できる。 記載するまでもないが, 参考までに図4に二電極式セルの概略図 を示す。里鉛側はニノケル線の先端を少し工夫し, 蝫鉛を装着で きるようにする。できるたけ電流が均一に里鉛に流れるように するために筆者は上述と同様, ステンレスメノシュに里鉛を包み設 置していた。リチウム金属と里鉛を十分に電解夜に侵債させ, シ リコーン栓上にある2本のニノケル線を短絡させる。これにより 里鉛電極とリチウム金属が同じ電位になり, 電解液中のリチウム イオンが黒鉛中に挿入する。グレートZZHHのHOPG $(6 \mathrm{~mm} \times$ $6 \mathrm{~mm} \times 1 \mathrm{~mm})$ を用いた場合でも2 3日でステージ 1 L1-GICが 生成する。

この手法ではステーシの制御ができない。そこで電気化学装 置を用いることによって電位を制御し, ステージ数を変えることが できる。ただし，後述するように大部分のリチウムイオンの星鉛 への挿入はリチウム金属に対して $100 \sim 250 \mathrm{mV}$ の範囲で生じ, 单 一なステージを得ることができる電位範囲を決めることが難しい ため, 均一なステーシ2 2 4 L1-GICを得るには試行錯誤が必要で ある。電気化学装置は電位制御できるものであればそれほど高 価なものは必要ない。例えば, ポテンショスタソトHA151 (北斗 電工社製) で十分である。先ほどの二電極式セルでは, リチウム 金属が先端にある二ノケル線には対極 (C E ) と参照極 (R E ) の線を繋ぎ, 黒鉛側のニソケル線に作用極（W E ）の線を繋ぐ。 この状態で開回路の電位を測定すると約 $3 \mathrm{~V}$ の電位を示す。ここ から電位を $250 \mathrm{mV}$ 以下の適当な電位にステンプさせる。用いる 里鉛の柆径により電位をステノプさせてから保持する時間が異 なってくるので, どの程度の時間保持すればよいかを記載すること はできない。ここからは実験を繰り返し, 設定電位と得られるステ ーシを調べる必要がある。電位とL1-GICのステージにつては, 小槻らの論文8)により丁寧に調べられている。

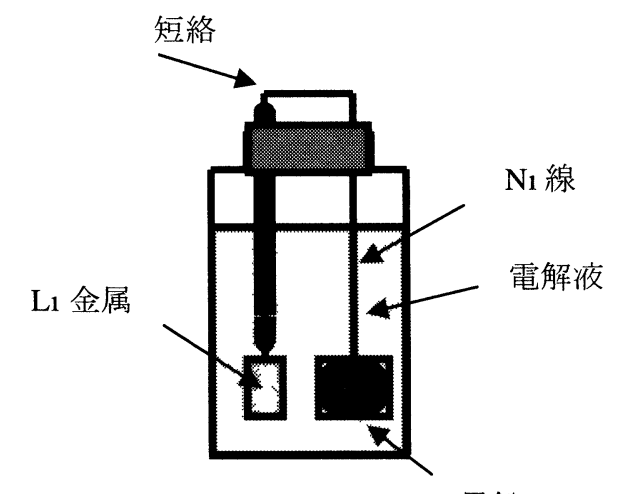

黒鉛
ここで記載したL1-GICの合成法と同様にほかのアルカリ金属GICの合成も可能であると考えられる。ただし, 電解夜については 市販のものがないため事前に調製する必要がある。この場合, 電 解質塩には $\mathrm{MCF}_{3} \mathrm{SO}_{3}(\mathrm{M}$ ：アルカリ金属）を用いればよいが, リ チウム塩のように溶解度が高くはなく, $1 \mathrm{~mol} \mathrm{dm}^{-3}$ とすることは 難しく,できるたけ溶解させた電解夜を用いる。また, 対極, 参照 極にアルカリ金属を用いることができればよいが,リチウム金属 ほと柔軟性はないため, 二ノケル線に設置することが難しいこと も容易に推側できる。この場合, 後迈の三電極式セルを用いるこ とによって,これらの問題占は解決できるかもしれない。

三電極式セルを用いたL1-GICの合成について記載する。リチ ウムイオン電他の基礎研究を精密にする場合には用いるセルに 工夫がいるが, 合成という観点から言えば, 比較的簡易な三電極 式セルで十分である。二電極式セルで用いたセルを利用し，これ にニノケル線をもう 1 本貫通させ, その先端にリチウム金属を付 けることにより三電極式セルとすることができる。このときの 注意点であるが, 参照極にはできるだけ電㐬が流れないようにする 必要があるため, 参照極の先端のリチウム金属は対極のリチウム 金属に対して非常に小さいものを使用する。作用極 (黒鉛電極) に流れる電流を考えて, 対極のリチウム金属はできるたけ大きくす る。また，参照極のリチウム金属は作用極に近つけたほうがよ い。三電極式セルであるため, 電気化学装置からの配線について は二電極式セルとは異なり, 参照極, 対極をそれぞれ別の二ノケ ル線に繋ぎ, 同様に電位を走査すればよい。また, 定電流を流し, 電位変化をプロノトすることによっていわゆる充放電曲線を得 ることもできる。図5に三電極式セルを用いたときの充放電曲線 を示す。リチウム金属に対して約 $1 \mathrm{~V}$ の部分に電位平坦分が認め られる。この電位では電解夜の還元分解が生じ, リチウムイオン 伝導性で電子伝導性のない不動態被膜 (いわゆる Solid Electrolyte Interface, SEI）が形成されている。SEIの詳細については以前炭 素誌で解説したのでそちらを参照していただければ幸いである9。 約 $200 \mathrm{mV}$ の電位より電位平坦部が3つ認められる。詳細は割爱 するが電位平坦部は二相共存領域であるので2つのステーシ構造 が混在している領域である。したがって, 電位がなだらかに変化し

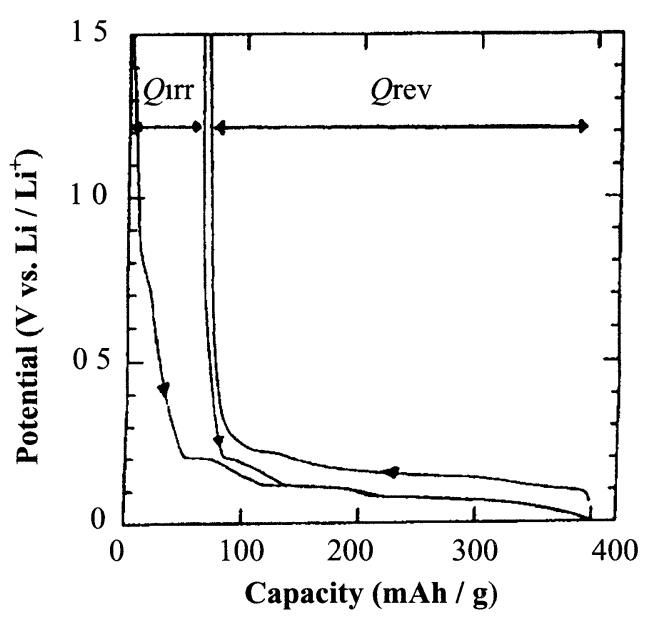

図5 黒鉛電極の典型的な充放電曲線 


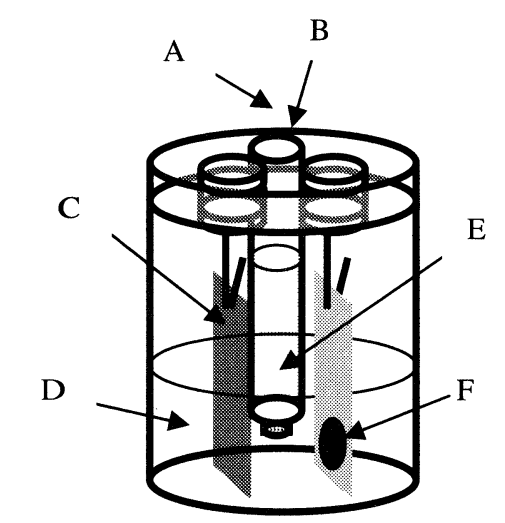

$\mathrm{A}$ ：銀線、B：サンプルホルダー、

$\mathrm{C}: \mathrm{Pt}$ メッシュ、 D : 電解液、

$\mathrm{E}$ : 参照液、 $\mathrm{F}$ : 黒鉛

図6 三電極式セル

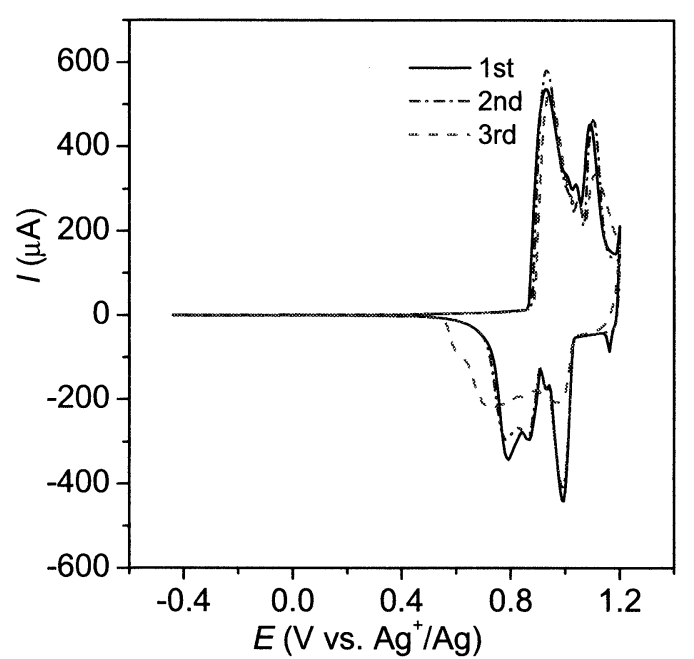

Fig. NG7 / 1M LiBF $-\mathrm{PC} / \mathrm{Pt}$

Sweep range : $-0.442 \sim 1.2 \mathrm{~V}$

Scan rate : $0.1 \mathrm{mV} \mathrm{s}^{-1}$

図7 $1 \mathrm{~mol} \mathrm{dm}-3 \mathrm{LiBF}_{4} / \mathrm{PC}$ 中での黒鉛のサイクリックボルタモ グラム：作用極には平均粒径 $7 \mu \mathrm{m}$ の天然黒鉛を使用 (NG7)

ているところでサンプルを取り出すことによって, 均一なステー ジ構造のものが得られる。

次にリチウム以外のアルカリ金属を用いるときの三電極式セ ルについて簡単に記載する。ただし, 筆者はこれから記載するセル でリチウム以外のアルカリ金属イオンの黒鉛への挿入実験を行 ったことがないので参考程度にしていただき，自分で工夫されたほ うがよいと思われる。ただし,このセルを用いて, 後述のアニオ ンの黒鉛への挿入脱離反応を詳細に調べているために, セルの構 成は問題ない。図6にそのセルの概略図を示す。

ここで工夫すべきポイントは参照極である。BAS 社製のサン プルホルダーを購入する (サンプルホルダーについてはhttp:// www.bas.co.jp/index.php?1439を参照されたい)。この先端はバ イコールガラス（液は混ざらないがイオンの通過はできる）より できている。このサンプルホルダー内に用いるアルカリ金属イ
オンを溶解させた電解液に 0.01 もくは $0.1 \mathrm{~mol} \mathrm{dm}-3$ トリフル オロスルホン酸銀 $\left(\mathrm{AgCF}_{3} \mathrm{SO}_{3}\right)$ を溶解させた溶液を注入する。 この溶液に銀線を入れることによって, $\mathrm{Ag}+/ \mathrm{Ag}\left(\mathrm{Ag}^{+}+\mathrm{e}^{-}=\right.$ $\mathrm{Ag})$ に対して電位を取ることができる。ただし, 銀を用いるので 遮光することが必要である。この銀電極の電位であるが,リチウム 金属基準に対して約 $3.6 \mathrm{~V}$ 程度であることが知られている。対極 は白金メッシュを用いることが望ましいが,ニッケルメッシュで も問題ないと思われる。このセルを用いて $\mathrm{BF}_{4^{-}}$アニオンを黒鉛 に挿入脱離させたときのサイクリックボルタモグラムを図7に示 した。

アニオンの黒鉛への挿入に対応する酸化ピークと脱離に対応す る還元ピークが明瞭に認められている。ただし, 電解液はプロピ レンカーボネート $(\mathrm{PC})$ に $1 \mathrm{~mol} \mathrm{dm}-3$ の $\mathrm{LiBF}_{4}$ を溶解させている。 図7の横軸の電位に $3.6 \mathrm{~V}$ を加えるとアニオンの黒鉛への電気化 学挿入反応はリチウム金属に対して約 $4.5 \mathrm{~V}$ 近傍から生じること がわかり，この結果は過去の論文とも良い一致を示している10)。

\section{3. 硫酸-GICの合成}

硫酸-GICについても化学的手法と電気化学的手法の 2 種類に より合成が可能である。硫酸-GICについては合成法およびその 物性について詳細に解説されている11)ため,ここではごく簡単に 合成法を記載するだけにとどめる。まず,化学的手法について記 す。市販の濃硫酸を購入し,これに硝酸, クロム酸などの酸化剂 を滴下する。筆者はクロム酸を主に用いていたが, 6価クロムで あるため現在ではあまりお蔦めできない酸化剤である。後処理 のことも考慮すると硝酸を用いるほうがよい。適当な量の硝酸 を硫酸に加え, この溶液に黒鉛を浸漬するだけで硫酸-GICが生成 する。硝酸と硫酸の混合比によって, 黒鉛を酸化する能力が異な るために得られる硫酸-GICのステージ数が異なる。これについ ては, 稲垣, 岩下による詳細な研究がある12)。彼らの研究では黒 鉛電極を $18 \mathrm{~mol} \mathrm{dm}^{-3}$ 硫酸中に浸漬させ, 電位が一定になった後 に酸化剤である硝酸を滴下し, 反応時間に対して電位変化を測定 している。硝酸／黒鉛のモル比を $16.3,3.3,0.33,0.17$ とし, 電位が ほぼ一定となった後にX線回折測定によりステージ数を決定し ている。その結果, モル比が16.3, 3.3ではステージ $1,0.33$ ではス テージ2, 0.17 ではステージ3であった。硝酸を酸化剤として用 い, ステージを制御する場合に非常に参考になる結果である。

次に電気化学的合成法について記載する。電気化学的手法に ついては上述の参考文献 11）に詳細に記載されている。藤井ら は硫酸-GICの電気化学的特性を検討する際に水銀／塩化水銀電 極を用いている。ここでは,できるだけ簡易な合成として, 白金 電極を参照極として用いた場合の合成法を記載する。Li-GICを 合成するときにサンプル瓶とシリコーン栓により三電極式セルを 作製した。このセル構成と同様にし，3本のニッケル線を白金線 とすることによりセルを構築する。作用極には白金線の先端に 黒鉛を設置する。濃硫酸を用いるため, 上述したステンレスメッ シュは使用できない。白金メッシュで黒鉛を包む，もしくは， HOPG かグラフォイルなどを用い, 白金線の先端に設置する。対 


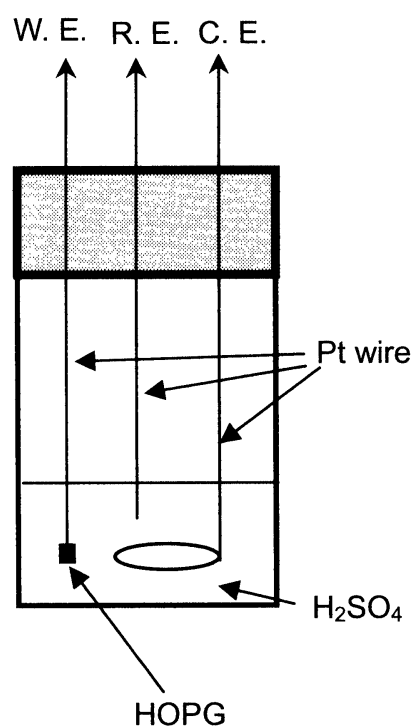

図8 硫酸-GIC 合成用三電極式セル

極には白金メッシュを用いるか,できるだけ表面積を稼ぐように白 金線を螺旋状にしたものを使用する。参照極の白金線は特に工 夫する必要はない。参考までに, このときの三電極式セルの概略 を図8に示す。

セルを組んだ直後に開回路電位を測定するとPt線に対してー0.1 $\sim 0.2 \mathrm{~V}$ 程度の電位を示す。そこで $\mathrm{Pt}$ 線に対して電位を正の方向 に掃引すると $0.7 \mathrm{~V}$ 近傍の電位から硫酸の黒鉛への挿入する様子 が肉眼でも観察できる。黑鉛への硫酸の挿入と同時に対極では 激しい水素発生が生じる。Pt 線に対して $1.0 \mathrm{~V}$ 程度の電位で保持 するとステージ1 硫酸-GICを得ることができる。硫酸-GIC の生成 反応はLi-GICの生成と比較して非常に速い。筆者は作用極に HOPG を用い, 電位掃引速度を $100 \mathrm{mV} / \mathrm{s}$ まで上げたことがあるが, $100 \mathrm{mV} / \mathrm{s}$ でも硫酸の挿入脱離が可能であった。硫酸-GICのステ ージ数を電気化学的に制御することも上述のLi-GICのときと同 様に可能である。電気化学装置を用い, 非常に小さな電流を流し, 時間に対する電位の変化を測定する。電位平坦部から電位平坦 部の間になだらかに変化する電位領域があれば, そこで電流をとめ, サンプルを取り出し, $X$ 線回折測定を行えば均一なステージ構造 を有する硫酸-GICが理屈のうえでは生成しているはずである。 電極に対して電流が均一に流れていない場合は，黒鉛の場所によ ってステージが異なるのでセルを構築するときは注意を要する。

硫酸以外のその他の酸についても電気化学的合成法が可能で ある。簡易に合成する場合は上述のセルを用い, Pt 線に対して黒 鉛電極を正の電位に保持してやればよい。また, 上述したように 定電流を流し, 電位変化を追うことによって, ステージ変化も観 察できるはずである。

\section{4. その他の GICのソフトプロセスによる合成}

上述以外にもソフトプロセスにより合成できる GICは多く知 られている。例えば, 塩山らは塩化鉄-GIC の電気化学的合成法 について詳細に報告している13)。また, 臭素, 一塩化ヨウ素など
は液体であり,これに黒鉛を浸漬することによってハロゲン-GIC の合成ができる。

これまでソフトプロセスによる GIC 合成が報告されていない 系でも化学的抒よび電気化学的手法を用いて GIC 合成が可能と 考えられる。上述では化学的と電気化学的手法を分けて記載し たが，ケミストリーは同じである。基本的に黒鉛をいかに還元する， もしくは酸化するかに帰結できる。したがって, 化学的手法では還 元剤, 酸化剂の選択が重要であり, 電気化学的手法では外部電源 によって作用極の黒鉛に電子を注入もしくは抽出することによ って黒鉛を還元および酸化させている。したがって,電解液を容易 に作製できる場合であれば電気化学的手法により GIC 合成が可 能となる。注意すべきはGICの生成がどの電位で生じるかであ る。電解液はその電位で安定である必要がある。電解液の作製 が困難な場合は, 化学的手法を用い, 適切な還元剂, 酸化剂を用い ることによって GIC 合成が可能となる。

\section{5. おわりに}

ソフトプロセスによる黒鉛層間化合物の合成について概説し, 特に電気化学的手法を用いた合成法を中心にそのセルとともに 紹介をした。今後, 黒鉛層間化合物を合成したみたいという学生 さんや研究者の方々に参考になれば幸いである。筆者も興味あ る GICがまだ多くあり,ソフトプロセスで合成しようと考えてい る。今後, どこかで紹介できればと思っている。

なお, 化学的手法に関する黒鉛層間化合物の合成については筆 者が京都大学原子エネルギー研究所 (現 京都大学エネルギー理 工学研究所) で水谷保男先生から 6 年間にわたって教えていただ いた内容であり,改めて感謝の意を表したい。

\section{文 献}

1）炭素材料学会編, 黑鉛層間化合物 (1990) リアライズ社.

2）渡邊信淳編著, グラファイト層間化合物 (1986) 近代編集社.

3) Graphite Intercalation Compounds and Applications (T. Enoki, M. Suzuki, and M. Endo), (2003), Oxford University Press.

4) M. S. Dresselhaus and G. Dresselhaus, Adv. Phys. 30 (1981) 139-326. (GICの総説として最も引用されて扔り,最近, Adv. Phys. Vol.51, No.1 (2002) 1-186として再揭載され, pdf ファイルとして入手できる).

5) Y. Mizutani, T. Abe, M. Inaba and Z. Ogumi, Synthetic Metals 125 (2001) 153-159.

6）ステージは侵入種 (インターカレート) と侵入種の間に存在する黒鉛 層の数で定義される。したがって, ステージ1では黒鉛層全層間に侵 入種が存在し, ステージ2では1層おきに存在する。

7) F. Beguin, B. Gonzalez, J. Conard, H. Estrade-Szwarckopt and D. Guerard, Synth. Met. 12 (1985) 187-193.

8) T. Ohzuku, Y. Iwakoshi and K. Sawai, J. Electrochem. Soc. 140 (1993) 2490-2498.

9）小久見, 安部, 稲葉, 鄭, TANSO 2002 [No.203] 136-140.

10）アニオンの黑鉛への電気化学的挿入反応は 1970 年代から研究され ている。最近の例では, J. Seel and J. Dahn, J. Electrochem. Soc. 147 (2000) 892-898.

11）文献2）のpp.281-342参照

12) M. Inagaki, N. Iwashita and E. Kouno, Carbon 28 (1990) 49-55.

13) H. Shioyama, M. Crespin, R. Setton and F. Beguin, Carbon 29 (1991) 1055-1056. 